\title{
Intersectional and Cross-Movement Politics and Policies: Reflections on Current Practices and Debates
}

\footnotetext{
S
} ome crucial social theory predicts that policies and movements that work against inequalities can be set up to achieve equality for certain disadvantaged, marginalized, or exploited groups but that social movements and policy makers will find it very hard to escape the dominant discourses that created the inequalities, especially if the subject position from which they choose to fight inequalities is linked to these discourses (Foucault 1972; Tilly 1998). Moreover, power mechanisms — such as opportunity hoarding by exploited or marginalized groups and adaptation to the categorical pairs that form the basis of exploitation-will be hard if not impossible to counter (Tilly 1998).

Yet historically we see that movements and policies can achieve progress toward equality, as has been the case for gender equality (Walby 2011). Even if it is clearly possible to highlight ongoing inequality, exploitation, and marginalization in the globalized world, there is a long list of exploited and dehumanized categories of people who have gained access to fundamental human and democratic rights over the last century, such as the right to education, to bodily integrity, to vote, to marry, to have property, to have equal access to public services, or to live as a family. This article does not challenge these achievements but uses strong theoretical arguments that predict an ongoing reproduction of inequalities to scrutinize how movements and policies deal with inequalities that interfere with one another. ${ }^{1}$ Are there ongoing inequalities within equality movements and policies, and how are they dealt with? The specific case at hand is feminist movements and gender equality policies and how they address what Kimberlé Williams Crenshaw (1989) calls political intersectionality.

This article sets out to find strategies that in one way or another try to counter the ongoing reproduction of inequalities within movements and policies. It does so by drawing on academic literature and other reports of political and policy practices, categorizing the different ways in which move-

\footnotetext{
${ }^{1}$ The concept of interference between inequalities is developed in Verloo (2009, 2011). I use "interference" as a broad term, as it is used in physics, to keep open the option that inequalities can strengthen one another, specify one another, or cancel one another out. Which of these they do is a matter of empirical evidence.
}

[Signs: Journal of Women in Culture and Society 2013, vol. 38, no. 4]

(c) 2013 by The University of Chicago. All rights reserved. 0097-9740/2013/3804-0005\$10.00 
ment and policy strategies address intersectional inequalities, and reflecting on their potential and their limitations. I find that current academic discussion and research suggest four different political and policy approaches to best address interference between inequalities, that is, to best address structural and political intersectionality: reactive approaches that focus on the importance of exposing stigmatizing or marginalizing effects, pragmatic approaches that highlight possibilities for intersectional politics within the confines of existing political and policy instruments, substantial approaches that call for a focus on structural change, and procedural approaches that center on the inclusion of particular groups of political actors.

The structure of this article is as follows: In the first section I focus on various types of gender equality policies and on more general mechanisms of inequality production and reproduction. I then present a framework of questions that I use to reflect on the potential and limitations of current movement and policy approaches that take interference between inequalities into account. The next section presents a short overview of recent developments toward intersectional politics in the European context, highlighting the need for a deeper understanding of the possibilities and dangers involved. The main section then presents four approaches that have been detected in movement and policy practices. I conclude by discussing the potential and limitations of these four approaches in terms of the conceptual questions presented earlier.

\section{Approaches in existing gender equality policies}

Equality policies are commonly believed to address social processes that turn differences between people - in how they live, what they own, who they are-into a basis on which one group of people exploits another or thwarts another group's chances of success in society. In this understanding, differences are seen as the raw material of inequalities, even if the differences involved are for the most part not seen as given but as social constructions resulting from historical and ongoing processes.

In the field of research on gender equality policies, the differences that are of concern are mostly differences in social, cultural, economic, and political status between men and women. Building on Judith Squires (2000), who categorized the various ways of understanding these differences, we can distinguish between understandings that see the two sex and gender categories as given and those that do not.

When gender equality policies principally accept the categories of men and women as given, there are two opposing takes. First, in strategies of inclusion, men and women are seen as basically equal human beings who 
therefore should have the same opportunities to engage fully in all social, cultural, political, and economical areas of life. This strategy wants to extend dominant values to all, irrespective of gender. It accepts the categories, as well as the dominant values, but wants to make them irrelevant. Second, in strategies of reversal, men and women are seen to be essentially different (whether because of biological characteristics or because of social experiences and life patterns), and the demand is for policies to shift from being based on the characteristics and life experiences of men to being based on the characteristics and life experiences of women. Another version of this strategy is the call for equal valuation of the different contributions of men and women to society (Walby 2011). In the practice of European gender equality policies, the strategy of inclusion is dominant, while there are some occurrences of a strategy of equal valuation of different contributions (e.g., in policies that grant mothers a salary for raising their children at home for the first three years; Krizsán et al. 2009).

In contrast, gender equality policies are also said to offer the option of transforming gender categories altogether. What Squires (2000) has labeled the strategy of displacement aspires to move beyond gender and is rooted in postmodern or poststructuralist feminism. It aims to destabilize the apparent opposition between equality and difference, between the strategies of inclusion and reversal, and seeks to displace patriarchal gender hierarchies and deconstruct discursive regimes that engender the subject. What is problematized is not (only) the exclusion of women, or the putting forward of men as a norm, but the gendered world in itself. The normative argument defending this position is that gendered identities are a product of particular political discourses. As such, this strategy sees gender categories themselves as an essential part of the problem. In practice, it is rare to see this strategy fully developed, although some partial appearances can be found (Verloo 2007). In European gender equality policies, there is not a single example of a policy that explicitly attempts to abolish gender categories. ${ }^{2}$ There are many examples of degendering in gender equality policies (Verloo 2007), but these can be seen to have a strong gendered subtext that does not destroy the gender categories themselves. ${ }^{3}$ Elsewhere, I have argued that in addition to a strategy of displacement, there is a simulta-

\footnotetext{
2 This has also sadly meant that trans* and intersex people have rarely, and then only recently, been included in gender equality policies.

${ }^{3}$ Degendering means that policies that are designed to work for gender equality are written without using the words "men" or "women," "male" or "female." Examples are to have policies that talk about "citizens who have to combine work and family life" or policies that outline what to do with "victims" and "perpetrators" of domestic violence.
} 
neous need for empowerment, for the creation of social, cultural, and political space that gives groups of women real chances to construct a world they would consider just (Verloo 2005). While the need for empowerment is crucial, it remains unclear how empowerment can be aimed for or achieved without referring to the sex and gender categories that the strategy of displacement wants to overcome. Thus, while both displacement and empowerment seem to be needed, the relationship between these two approaches is at best unclarified and may be problematic because they seem to take a different position on categorical identities.

\section{Understanding category making as (re)producing inequality: Tilly}

Charles Tilly's theory of durable inequality (1998) could be helpful in furthering our understanding of how positions on categorical identities affect the chances of abolishing inequalities. His theory primarily provides an explanation for the preservation of inequality through the social construction of categorical pairs, that is, through classifications of people into two exclusive and exclusionary groups. Tilly sees the borders drawn between the two halves of a categorical pair as essential to the creation and preservation of inequality. ${ }^{4} \mathrm{He}$ describes the rise and continuous reproduction of inequality through four mechanisms: exploitation, opportunity hoarding, emulation, and adaptation. The exploitation mechanism comes into effect when people with a certain amount of power are able to create added value through the efforts of outsiders, people who do not belong to the exploiter's category. Capitalism is a fine example of this mechanism at work. The second mechanism, which Tilly calls opportunity hoarding, is also present within groups and among people who lack power. When members of such a group acquire access to a resource that is renewable and could prove profitable in the long run, they will try to monopolize the access to this resource for their own group. Tilly offers the example of migrants' networks and the way they marshal specific know-how about particular professions within their network. Take, for instance, the first Chinese migrants to the Netherlands, who specialized in setting up successful "exotic" restaurants, or the Bengali migrants in Vienna, who have monopolized the market for street-side magazine and newspaper sales. Both groups

\footnotetext{
${ }^{4}$ The fact that Tilly here reinvents a wheel long spinning in gender studies is painfully typical proof of gender studies' isolation (or exclusion) in the social sciences (see Butler 1988; Brouns, Grünell, and Verloo 1995). Other scholars have also pointed out the parallel but in a way that is seemingly independent of developments in gender studies and other social sciences (Kenny and Mackay 2009).
} 
share the knowledge needed for success in this foreign territory only within their own networks. Through this opportunity hoarding and the monopoly on specific knowledge, inequality is created or reinforced. In the case of the United States, Dvora Yanow has convincingly shown that race and ethnicity became embedded into law and policy, what effects this has had, and how those categorized by such policies also benefit from the preservation of these racial categories, thereby revealing an American mechanism of opportunity hoarding (2003).

To Tilly, these mechanisms do not consciously create inequality. Rather, the emerging inequality is simply a by-product of people's improvised attempts to stake a claim for their livelihood. This inequality, however, becomes more durable through the effects of two other mechanisms: emulation of older, existing social categories in new settings and adaptation, which Tilly sees as the development of daily routines based on categorical pairs and the justification for these routines in a certain era and context. Emulation is the copying of established, categorically based organizational models or the transplanting of existing social relations from one setting to another (Tilly 1998, 174). An example of emulation can be seen in the way gender inequality in families is replicated in the labor market, with its division between men's and women's professions. This mechanism resembles what Georgina Waylen calls "institutional layering," whereby new institutions are most often built atop or within existing institutions due to a lack of means for innovation $(2009,247)$. Tilly believes that this emulation also replicates the unequal division of labor in the home-where women perform unpaid labor for men - within the labor market: women (and men) are paid less for work resembling housekeeping or care. ${ }^{5}$ The adaptation mechanism's most important characteristic is its socialization process, through which even the least privileged develop routines based on existing structural inequality.

Those who exploit others, or who hoard opportunities, are constantly deciding where to draw the line between their own group and those excluded; how to ensure solidarity, loyalty, and control; and how to monopolize knowledge that might help them, or members of their own network, advance. Copying categorical pairs from elsewhere not only helps make all these decisions, it also reaffirms these pairs and, thereby, the attendant inequality as well.

Tilly is quite pessimistic about the chances that politics and policy might reduce or altogether remove inequality. He suggests that nations, too, are

\footnotetext{
${ }^{5}$ See Katz, Stern, and Fader (2005) for a wider analysis of the durability of inequality in women's employment in the United States, based on Tilly.
} 
subject to his four mechanisms and adds that nations can also fix categorical pairs in the letter of law and are well equipped to sanction encroachers. Indeed, even democratic states are no strangers to exploitation or to determining categories of people who can and cannot hoard opportunities. States after all are able, as the Netherlands did, to decide that "anyone" is allowed to marry at age eighteen, except for those citizens with partners from less developed countries, who will have to wait until they are twentyone and earning 120 percent of the legal minimum income. States can also, as in the case of Austria and too many other countries, determine that certain citizens are not allowed to marry each other, simply because they share the same gender. All nations thus categorize their citizens, setting grounds for inclusion and exclusion. Members of dominant categorical groups always have more possibilities for exploitation or opportunity hoarding, but even in democratic arrangements in which the effects of categorical inequality are mitigated, there are seldom state-led attacks on unequal categories themselves. Therefore Tilly deems it inadvertent but unsurprising that welfare states have often amplified inequality between the sexes (Haavio-Mannila 1993; Siim 1994; Orloff 1996).

It was not until the broadening of the franchise within democracies that nations explicitly attempted to fight inequality by redistributing wealth or goods. Although these attempts were historically often advocated by social movements, Tilly does not believe these movements to be free from the reach of categorical pairing either. Even if their aim is to contest the unjust treatment of the "weaker" half of a categorical pair, social movements still create new, or activate existing, categorical pairs themselves. In their fight for inclusion, movements try to present their chosen category as clearly as possible, thus excluding or downplaying other categories. Tilly's pessimistic views thus take the form of a critique of what gender studies dubs identity politics. In his view, only a strategy of displacement can be expected to bring about equality because only this strategy attacks the essential building block of all his inequality-creating mechanisms: categorical pairs.

\section{Cross-movement politics and equality policies}

On the basis of the different types of gender equality policies and their different potential to address gender inequalities and bring forward gender equality, I present the following main questions to reflect on the potential and limitations of the four approaches found in cross-movement politics and in early intersectional equality policies: How does each of the approaches affect equal treatment and inclusion of intersectional groups (and 
persons subject to multiple forms of discrimination)? How do they affect strategies of reversal or calls for the equal valuation of different contributions? To what degree can each of the approaches displace categories that are fundamental for reproducing inequality, and to what degree is displacement visibly developed as a strategy? To what degree can intersectionally situated persons and groups contribute to empowerment, and how does this empowerment escape the negative effects of identity politics?

\section{Widening the scope of gender equality policies}

Recently, and especially in the policies of the European Union and its member states, there has been increased attention to inequalities other than those based on gender (mostly race/ethnicity, sexual orientation, age, religion or belief, and disability), both as separate policy concerns and as related to gender equality policies (Verloo 2006; Kantola 2010; Woodward 2012). In the context of gender equality policies, and in the wider context of gender studies, this has led to debates about the concept of multiple inequalities, or intersectionality (Lombardo and Verloo 2009; Walby 2011). Crenshaw introduced the concept of intersectionality as an escape from the problems of identity politics, to "denote the various ways in which race and gender interact to shape the multiple dimensions of Black women's employment experiences" (1989, 139). She distinguishes between structural intersectionality and political intersectionality (Crenshaw 1991). Structural intersectionality occurs when inequalities and their intersections are directly relevant to the experiences of people in society. Political intersectionality indicates how inequalities and their intersections are relevant to political strategies and how strategies regarding one axis of inequality are seldom neutral toward other axes.

An important part of publications and research on intersectionality is theoretical in nature. This work largely contemplates the way different inequalities relate to one another and what that means for both research into inequality and societal inequality itself. ${ }^{6}$ The developments in practice largely seem to be centered on the quality of the equality architecture, on whether to have administrative agencies that deal with all (or a range of) inequalities or to have separate agencies for all inequalities deemed relevant in a particular context (O'Cinneide 2002; Krizsán et al. 2009; Walby, Armstrong, and Strid 2012). There are also ongoing debates on the range of inequalities to include in equality policies. Some member states restrict

${ }^{6}$ See McCall (2005), Yuval-Davis (2006), Hancock (2007), Walby (2007), and Weldon (2008). 
their policies to the range included in the European Directives (Verloo and QUING Consortium 2012), while other member states choose to have a wider range than the EU mandates (e.g., Belgium, which since 2007 has had policies addressing seventeen possible discrimination grounds: nationality; race; skin color; national or ethnic descent; gender, including transsexuality; age; sexual orientation; civil status; status as nobility or commoner; wealth; belief/religion; political preferences; language; current or future health; disability; physical or genetic characteristic; or social descent [Centrum voor Gelijkheid van Kansen en Racismebestrijding 2008, 12-13]).

Moreover, in practice the widening of attention to include inequalities beyond gender has strengthened antidiscrimination policies, giving rights to claimants on the basis of a number of grounds for redress or compensation (Lombardo and Verloo 2009; Lombardo and Rolandsen Agustín 2012). In this, discrimination is seen as taking various forms: single-ground discrimination, when an individual is put at a disadvantage on the basis of one inequality ground; additive multiple discrimination, if an individual belongs to two (or more) groups that separately suffer discriminatory practices; or intersectional discrimination, based on the indivisible combination of two or more social characteristics that create a situation that is not equal to the sum of discriminations on separate grounds (Hannett 2003, 68).

The widening of gender equality policies has triggered a number of developments that have strengthened identity politics: the question of which categories one is seen as belonging to now matters even more, as some categories are protected, and the protection offered to different categories is uneven. ${ }^{7}$ In Tilly's terms, this uneven protection triggers opportunityhoarding mechanisms that reproduce inequality.

In this relatively new European context of multiple equality policies, it becomes all the more apparent that gender equality policies categorize on the basis of gender and other social and political boundaries at the same time. While gender equality policies have always assumed attention for certain subcategories of women, they now are becoming more explicit about it, and there is a higher demand for accountability regarding their potential to deliver results for intersecting inequalities (Lombardo and Verloo 2009; Krizsán, Skjeie, and Squires 2012; Lombardo and Rolandsen Agustín 2012). This highlights the political relevance and salience of this article's questions about the potential of gender equality policies, and it demonstrates the need for movements working for gender equality to engage in intersectional strategies.

${ }^{7}$ For a more detailed analysis of the unevenness in the protections offered by EU equality policies, see Lombardo and Verloo (2009). 


\section{Decategorizing or demarginalizing in the context of gender equality policies or strategies: Four different options}

In this section I attempt to categorize the different strategies that have been outlined to address and abolish intersecting inequalities. This overview is tentative and open to further elaboration and debate. For now, I find that current academic discussion and research suggest four different political and policy approaches to best address interference between inequalities. It will become clear that in most cases this interference involves intersectional inequalities, meaning that unequal positions intersect via more than one dimension of inequality (Verloo 2009). Where relevant I will distinguish between approaches at the level of movement strategies and practices and approaches at the level of policy making.

The first approach that I distinguish is reactive. It concentrates on pointing out the degree to which strategies that are presented as addressing interfering inequalities are de facto counterproductive, leading to the stigmatization of the targeted group. This approach pleads for the unmasking and eradication of such stigmatizing distortions. An example can be found in an analysis I conducted with Conny Roggeband (Roggeband and Verloo 2007). This analysis of Dutch policy found that, between 1995 and 2005 , the case of migrant women became an almost emblematic policy problem. We argued that the Dutch government created and fixed in law a new categorical pair: the migrant population and the native Dutch, or in geological terms, as the Dutch would have it, the allochthonous and the autochthonous. This stigmatizing and marginalizing of migrant women and women of migrant descent was the result of the political dynamics between parties on the Left and the Right. Left-leaning political parties originally placed allochthonous women on the political agenda, intending to address their difficulties in accessing social and economic participation in society, but it was the right-wing parties that determined the stigmatizing policies addressing the issue.

The new Dutch regulations for transnational marriage involving people from non-Western countries (described above), for instance, place women in a vulnerable, dependent position, and emancipation and integration issues become more and more individualized and culturalized. The government essentially tells allochthonous women that it is their duty to emancipate themselves from their "problematic culture"-a euphemism for Islamic culture. This sparked a racialization process in the Netherlands, one that falsely posits gender equality as an already realized core value of Dutch society. Birte Siim and Hege Skeje (2008) note a similar process in Denmark, where the issue of gender equality also gained in status, becoming a core national value, and was thereafter used to emphasize the 
inferiority of other (Islamic) cultures as embodied in migrant communities. Helga Eggebø (2010) finds similar processes in Norway.

What at first was only a question of religion and national background has, in Dutch politics (often explicitly) and policy (largely implicitly), become more and more a question of race, with the "Muslim" label as the defining quality of that race. David Theo Goldberg remarks that this is a specifically European form of race construction, and one with historical resonance: "The figure of the Muslim, alongside that of the Jew, has historically bookended modern Europe's explicit historical anxieties about blackness" (2006, 344).

Although the government now states it wants to discourage any negative branding of allochthonous people, the government itself contributes heavily to this branding through its categorization and through the different demands made of allochthonous and autochthonous citizens (Yanow and Van der Haar 2012). Exposing the government's counterproductive efforts as well as those political viewpoints that contribute to inequality would be an important part of any effective intervention, and academia in particular could contribute to such a process. The reactive approach is also used by movements and organizations that address the interference between inequalities. A good example of such a group is NextGENDERation (2004), whose manifesto, “Niet in onze naam!” (Not in our name!), rejects any cooperation with xenophobic political parties. These parties may claim to fight for gender equality, but NextGENDERation believes that their ultimate aim is the exclusion of migrants and therefore does not believe that they can ever be potential allies in the struggle for gender equality.

The other three approaches I have identified have in common that they call for demarginalization, going a step further than diagnosing what the problem is and how it was created. The first one is a pragmatic approach, suggesting that complex interferences between inequalities do not necessarily require complex new policy instruments or measures. Margaret L. Satterthwaite (2005) convincingly shows that the specific problems of women migrant workers can be adequately tackled with existing policy instruments. Her work meticulously reconstructs the problems migrant female domestics can face, and her list is long: exploitative terms of work, pay, hours, and contracts; restrictions on freedom of movement; labor market discrimination against women at home and abroad; dangerous and degrading working conditions; gender-based violence in the workplace; gendered forms of racism and xenophobia against women migrant workers; and restrictions on migrant women's ability to organize for their rights.

Satterthwaite's approach, which we might call applied intersectionality, places existing human rights treaties side by side with these prob- 
lems, showing that all of the problems can be addressed using existing treaties. The five treaties she uses are the Convention on the Elimination of All Forms of Discrimination against Women; the International Covenant on Economic, Social, and Cultural Rights; the International Covenant on Civil and Political Rights; the Committee on the Elimination of Racial Discrimination; and the Migrant Workers Convention. She concludes that a specific treaty on the rights of female migrants is not necessary since the current treaties should suffice, providing that they are intersectionally applied. Of course, her study does not prove that applying intersectionality will always work, but it convincingly shows that this option should not be overlooked and that actors involved in fighting the intersectional inequalities of migrant women workers have potential agency within current laws and regulations.

The applied intersectionality approach is of interest to all polities, including the member states of the European Union and the European Union itself, all of which are struggling with how to tackle inequality, especially given the interference between different inequalities. The EU member states currently deal with this issue in different ways: some have dozens of laws addressing inequalities in various contexts, others only have a few; some have instigated one overarching institution meant to monitor all inequality issues, others have separate institutions for the inequalities they have deemed relevant. All this makes Europe a kind of laboratory for comparative research (Krizsán, Skjeie, and Squires 2012). As part of the QUING (Quality in Gender Equality Policies) project, for instance, a comparison was made between the Netherlands and Belgium, simply asking whether the fact that these countries have different kinds of institutions set up for equal treatment makes a crucial difference to people who find themselves the victims of intersecting inequalities (Verloo et al. 2012). ${ }^{8}$ In which institutional arrangements are migrant women or other groups suffering from intersectional inequalities better off? The answer in this analysis is that in both countries some progress has been made in paying attention to intersectionality. Yet neither integrated institutions (such as those in the Netherlands) nor integrated policy (as in Belgium) suffices to adequately tackle intersectional inequality since in both cases there is a need to adapt the institutions and to actively change existing routines and interpretations. Although actors matter in the sense that their creativity and engagement can make a difference, they do face barriers; the existence of separate administrative bodies, fragmented laws, and uneven protection in particular seem to constitute barriers to fully applying intersectionality in practice.

\footnotetext{
${ }^{8}$ See also http://www.quing.eu.
} 
Another demarginalization approach, in contrast, is rather more substantial or structural. This approach argues for intervention in the principles and categories that underlie policy settings or movement strategies, not just intervention in the measures taken on the basis of long-standing (often sexist, racist, or homophobic) social, cultural, and political goals or in the decisions movements and organizations make about new activities. ${ }^{9}$ A structural approach instead pleads for a kind of equality mainstreaming to alter societal structures that fix inequalities of various natures. These structures almost always make distinctions between citizens. A historical example would be the fact that in many places in Europe the right to vote was once directly related to a certain minimum income. More contemporary examples are the breadwinner principle in social security, higher income standards for people of migrant origin who wish to marry someone from a non-Western nation, or limiting access to in vitro fertilization procedures to women who are heterosexual or married. Inequality policies cannot be effective if they merely stop discrimination by individuals. Inequality can only truly be addressed if all parts of society are examined for existing measures that enable exploitation or opportunity hoarding, for the transfer of categorical pairs to other domains, and for the justifications and adaptations involved in producing inequality (Tilly 1998). One example hits quite close to home: if we want to change the unequal gendered division of high-power positions at universities, demanding rigorous equality in selection procedures will have less of an effect than changing the networks through which candidates are scouted. Only when we truly understand the gender-specific ways in which the chances to be considered for these positions are hoarded can better interventions be planned (for more a detailed analysis of this, see Van den Brink, Benschop, and Jansen 2010).

All European nations (alongside many on other continents) agreed to implement gender mainstreaming when they took part in the Beijing Fourth World Conference on Women in 1995. This agreement entailed that, before introducing any new policy or legislation, they would perform studies to make sure the new policy or law would not contribute to gender inequality. Fourteen years later, if there is one thing that has become clear, it is that this approach, apart from being substantial and possibly revolutionary, is utopian at best and extremely difficult to implement, to say the least (Verloo 2001; Walby 2005; Meier and Celis 2011). To introduce and implement something akin to equality mainstreaming or intersectionality mainstreaming, as some argue for (Verloo 2006; Lom-

9 This reasoning is parallel to Ange-Marie Hancock's (2009) argument for an untraditional intersectional analysis of the 2008 US election. 
bardo and Rolandsen Agustín 2012), is therefore an ambition with simultaneously great potential in terms of content but low potential in terms of its chances of realization.

One of the rare attempts at designing a form of mainstreaming that includes multiple possibly intersecting inequalities is the evidence panel model designed and tested in Wales (Parken 2010; Hankivsky and Cormier 2011). The multistrand approach in these evidence panels is intended to engage with all relevant stakeholders, setting out a process of collaboratively mapping existing inequality, envisioning desired futures, roadtesting possible scenarios, and monitoring and evaluating outcomes. This approach has been partially tested in Wales in the field of social care (with only the first two steps undertaken). The fact that it has only been tested in part illustrates once more the problem of making such ambitious structural approaches viable.

There is also an occasional example of a handbook that outlines how to address intersectionality in the development of violence prevention. Olaf Stuve et al. (2011) present a comprehensive handbook for the European context with online tools for intersectional peer violence prevention. This handbook provides a range of tools for trainers and social workers working with adults and young adults. On the basis of expert interviews, the authors identified intersections of gender, class, ethnicity, religion, and sexuality as crucial for dealing with peer violence, and these are the main focus of the tools presented across a policy cycle, namely, the identification of needs and the development and evaluation of new policies. As befitting a handbook, its tone is optimistic and the demands comprehensive. There are no accounts yet of its actual application.

The last approach for demarginalizing that I identified is procedural, which does not focus on what to do but on how to actually shape the political process and on who should have a voice in this process. This approach can be seen as a plea for a deepening or renewing democracy. At its heart, this approach pleads for the inclusion of other often marginalized groups in the decision-making process, often within the framework of deliberative democracy. It remains to be seen, however, whether marginalized groups can truly be heard in our current democratic system; power struggles taking place outside the political system cannot be put between brackets (Fraser 1990).

Aside from questions about the possibilities, backgrounds, and consequences of democracy renewal, the question I deem most relevant here is the possibility for agonistic struggle in democracy (Schmidt-Gleim and Verloo 2003; Rummens 2009). On a practical level, this implies attention to the degree to which groups within civil society have the chance to con- 
tribute, more or less directly, to the design or implementation of policies to fight inequality. Data from the QUING project (Krizsán et al. 2009) reveal great differences among how various EU member states refer to groups of people in their legislative and policy documents, and there are also differences in the voice and standing given to civil society groups depending on the policy issues being studied. Across issues, the references to involving civil society in consultation processes are lowest in discussions of nonemployment (policies that legitimize nonemployment as an exception to the routine expectation of employment, such as pension and leave regulation policies), followed by discussions of intimate citizenship and genderbased violence. Leah Bassel and Akwugo Emejulu (2010), building their analysis of intersectionality on the politics of institutional policy rather than on identity, show how in both the United Kingdom and France the newly established equality institutions operate through a logic of separation that "severely curtails the institutional space available for ethnic minority groups to make complex and intersectional social justice claims" (517). In the United Kingdom, the logic works through the treatment of various marginalized minority positions as independent and unconnected, while in France the logic separates antidiscrimination and integration to similar effect.

Another aspect of the discussions of and contributions to this approach attempts to understand the competition between movements - the term used is the oppression olympics (Martinez 1993) — and studies the possibilities and problems inherent in forging coalitions between different movements. Cross-movement politics is severely hindered by the opportunityhoarding mechanisms connected to category making. Elisabeth Cole (2008) believes that inequality interference causes both movements and policy makers to pay attention only to those people who, but for one characteristicgender, class, or sexuality-would be privileged in status. Her research not only considers intersectional inequality but also includes a focus on privilege as well as disadvantage and discrimination. Research has since shown that competition between movements is certainly problematic and that inequality interference causes inequality to arise even within these movements. Identity politics can clearly further boost the negative effects of competition. Convincing findings have been presented by Dara Z. Strolovitch, who analyzed the policy advocacy of US organizations that represent marginalized groups. Combining quantitative analysis of original data from a survey of organizations with information from in-depth interviews, she found that organizations are substantially less active when it comes to issues affecting disadvantaged subgroups than they are when it comes to addressing issues that affect more advantaged subgroups. In spite of sincere desires 
to represent disadvantaged members, organizations downplay the impact of such issues and frame them as narrow and particularistic in their effect, while framing issues affecting advantaged subgroups as if they affect a majority of their members and have a broad and generalized impact. Consequently, issues affecting advantaged subgroups receive considerable attention regardless of the breadth of their impact, whereas issues affecting disadvantaged subgroups do not (Strolovitch 2006). However, her study also found that some organizations do speak extensively and effectively on behalf of intersectionally disadvantaged subgroups of their constituencies. What distinguishes these organizations from those that fail to provide effective representation of intersectionally disadvantaged groups is a set of principles and practices that Strolovitch (2007) labels "affirmative advocacy." Affirmative advocacy principles and practices recognize that equitable representation requires proactive efforts to overcome entrenched biases persisting against marginalized groups and to create decision-making rules that elevate issues affecting disadvantaged minorities on organizational agendas.

Movements are always shaped by their alliances and the connections they make when acquiring the means to advocate their cause. Back in 1987, Judith Adler Hellmann showed that, in the case of the Italian women's movement, different alliances at local levels caused organizations to take their activism in very different directions (1987). She makes it clear that alliances are rooted in both the material (e.g., spaces to hold meetings) and the discursive (sharing certain ideas). Framing - that is, the specific way a movement or policy defines the problem, how it came into being, and who is responsible for its resolution (Verloo 2007; Lombardo, Meier, and Verloo 2009) - is a crucial element in the formation or obstruction of alliances since overlapping problem definitions form the discursive basis of any alliance (Ferree 2009). Divergent framing often works to obstruct alliances. Davina Cooper (2004) provides a powerful example of how disagreement over the "problem" of the dichotomous character of gender hinders any cooperation between the women's and transgender movements. In crossmovement politics, identity politics is a negative force. According to Cole (2008), successful coalitions are not based on shared identities but on sharing a similarly marginalized relationship to power. ${ }^{10}$ She also notes that effective coalitions address power differences within the movements themselves. Cole cites as a best case scenario the American March for Women's Lives, which at first was only planned to address abortion and the right to choose but later, in a successful attempt to include African American women,

10 This echoes Iris Marion Young's (1995) concept of seriality, inspired by Jean-Paul Sartre. 
was broadened to address a larger set of reproductive rights (the right to have children, to retain custody, etc.), changing the makeup of the organization in the process.

A recent study on the intersection between class, gender, gender identity, and sexual orientation in the $15 \mathrm{M}$ movement in Spain also focuses on factors that are important in shaping the potential joint framing of social problems. ${ }^{11}$ Using an analysis of documents produced by the movement, participant observation, discussion groups in Madrid and Barcelona, and interviews, Marta Cruells and Sonia Ruiz (2012) conclude that two organizational factors play a crucial role. They show that the systematic participation of certain (groups of) activists is a key factor in producing intersectional frames and discourses, explaining the presence and absence of discourses in terms of the presence or absence of activists (e.g., gender identity and sexuality activists and frames present, religious- and ethnicgroup activists and frames absent). The presence or absence of certain (groups of) activists is in turn produced by the openness or closedness of what Cruells and Ruiz call "nodes," organizational formats for different kinds of assemblies within the $15 \mathrm{M}$ movement. Hence, the main questions of studies in the procedural approach concern the factors that produce different coalition potentials, thereby overcoming a focus on identity politics.

\section{Conclusion: The potential and limitations of the four approaches}

This article began by highlighting the limited possibilities of policies addressing the (re)production of inequalities, arguing that there are powerful mechanisms that prevent equality policies from being effective in pushing equality forward and that lead them to reproduce or sustain inequality instead (Tilly 1998). The questions resulting from the theoretical reflection in the first sections of this article were: How does each of the approaches affect equal treatment and inclusion of intersectional groups (and persons subject to multiple forms of discrimination)? How do they affect strategies of reversal or calls for the equal valuation of different contributions? To what degree can each approach displace categories that are fundamental to reproducing inequality, and to what degree is there a visible development

\footnotetext{
${ }^{11}$ Similar to the Occupy movement in the United States, the $15 \mathrm{M}$ movement, which draws its name from its starting date on May 15,2011, presents a broad network of claims for social justice and radical democracy as well as the intense convergence of struggles for equality (Cruells and Ruiz 2012, 5).
} 
of displacement as a strategy? To what degree can intersectional persons and groups contribute to the empowerment of intersectionally situated persons and groups, and how does this empowerment escape the negative effects of identity politics?

The first approach, the reactive approach, joins Tilly in calling for an analysis of how exactly this happens and in transferring the information about the results of such analyses to policy makers and movement activists so they can be resisted. A reactive approach could be useful in policy making as part of an intersectionality impact assessment (Lombardo and Rolandsen Agustín 2012) or any evaluation of previous policies by policy insiders or outsiders. Under conditions of dedemocratization in Europe (Verloo 2011; Walby 2011) and governments opposed to equality for certain groups (such as Muslims and Roma), such reactive exposure of stigmatization and marginalization could aim to trigger a spiraling sequence of events that might improve social justice and human rights (Risse and Ropp 1999). Within movements, this approach could also be helpful as part of a reflexive evaluation of previous and current practices. As the reactive approach is an oppositional one, it can afford to choose any of the three equality perspectives and can choose a fundamental focus on categorical displacement. While this appears to be a strength, its oppositional character means that this approach has no easy link to implementation or translation into action and therefore can only be empowering if groups that are affected by intersectional inequality are involved in the analysis.

It is harder to assess the merits of the three approaches that attempt to counter inequality-reproducing mechanisms, partly because they put different sets of stakeholders in the spotlight and partly because they are based on different goals. For the pragmatic approach, the stakeholders are lawyers, legal advocates, and legislators, who are given an alternative to the endless splitting of laws to treat different inequalities and the infinite making of subcategories. It would seem that this approach will resonate more with inclusion perspectives than with displacement or reversal perspectives. The pragmatic approach is based on stretching existing laws and regulations so that intersectional inequality, in the form of justice for intersectional categories of people, can be addressed. As such it is vulnerable to the discursive dynamics of "stretching" that can be negative (watering down the focus on gender or another inequality) or positive (a more intersectional development of gender; Lombardo, Meier, and Verloo 2009). Classic power mechanisms, such as preexisting resources or decision-making access, can be expected to determine whether the outcome will be positive or negative. Given the dominance of nonintersectional equality institu- 
tions and laws, the power conditions will not necessarily be favorable for intersectional outcomes.

For the structural approach, the stakeholders are civil servants and policy makers but also researchers who could expose the ways certain policies are based on categories that might be eliminated or neutralized in future policies and explore and outline how that can be done. Whether this approach can actually deliver on its structural character will largely depend on the ambition and power of the stakeholders. As with gender mainstreaming, which is also seen as a structural approach, policy reality can be expected to be watered down compared to the original visions. In a technocratic form, empowerment is unlikely, while in a more participatory form (such as the evidence panel), empowerment seems a possibility.

For the procedural approach, a wider set of stakeholders comes into view. When it comes to democracy renewal, politicians and active citizens, as well as nongovernmental organizations, are on the demanding side, while policy makers and legislators can scrutinize the regulations and routines of democratic practices for how they channel certain categories in and others out of democratic deliberations and struggles. Cross-movement politics are deeply embedded in political opportunities and therefore also shaped by the possibilities they have. To make progress they would need not only the attention and motivation of movement activists (who could have a stronger sense of intersecting interests) but could also profit from opportunity structures that would offer fewer incentives for competition and more for cooperation across movements. Here, too, further research could analyze the interplay between the incentives incorporated in certain policies and the decisions made by movements addressing various inequalities. Such research could be very beneficial to creating more productive cross-movement politics, thereby decreasing intersectional inequalities. A crucial element seems to be that cooperation and alliances are facilitated by shared framing and therefore also by a focus on issues rather than identities. Insofar as movements are strongly identity based and focused on the empowerment of groups that face discrimination based on their identities, strategies of inclusion are more likely to be pursued and to succeed, while strategies of reversal, which prioritize one identity, seem difficult to combine with an intersectional focus, and strategies that displace categories seem unlikely to be incorporated if identity is a strong base.

Department of Political Sciences and Institute for Gender Studies

Radboud University Nijmegen

and

Institute for Human Sciences, Vienna 


\section{References}

Adler Hellmann, Judith. 1987. Journeys among Women: Feminism in Five Italian Cities. New York: Oxford University Press.

Bassel, Leah, and Akwugo Emejulu. 2010. "Struggles for Institutional Space in France and the United Kingdom: Intersectionality and the Politics of Policy. Politics and Gender 6(4):517-44.

Brouns, Margo, Marianne Grünell, and Mieke Verloo, eds. 1995. Vrouwenstudies in de jaren negentig: Een kennismaking vanuit verschillende disciplines [Women's studies in the nineties: A multidisciplinary introduction]. Bussum: Coutinho.

Butler, Judith. 1988. "Performative Acts and Gender Constitution: An Essay in Phenomenology and Feminist Theory." Theatre Journal 40(4):519-31.

Centrum voor Gelijkheid van Kansen en Racismebestrijding. 2008. "Discriminatie en diversiteit: Jaarverslag 2007" [Discrimination and diversity: Annual report 2007], Centrum voor Gelijkheid van Kansen en Racismebestrijding, Brussels.

Cole, Elisabeth. 2008. "Coalitions as a Model for Intersectionality: From Practice to Theory." Sex Roles 59(5-6):443-53.

Cooper, Davina. 2004. Challenging Diversity: Rethinking Equality and the Value of Difference. Cambridge: Cambridge University Press.

Crenshaw, Kimberlé Williams. 1989. "Demarginalizing the Intersection of Race and Sex: A Black Feminist Critique of Antidiscrimination Doctrine, Feminist Theory and Antiracist Politics." University of Chicago Legal Forum 1989: 139-67.

- 1991. "Mapping the Margins: Intersectionality, Identity Politics, and Violence against Women of Color." Stanford Law Review 43(6):1241-99.

Cruells, Marta, and Sonia Ruiz. 2012. "Political Intersectionality in Current Social Mobilizations: Factors at Stake." Paper presented at the preconference of the International Political Science Association, Madrid, July 7.

Eggebø, Helga. 2010. "The Problem of Dependency: Immigration, Gender, and the Welfare State." Social Politics 17(3):295-322.

Ferree, Myra Marx. 2009. "Inequality, Intersectionality and the Politics of Discourse: Framing Feminist Alliances.” In Lombardo, Meier, and Verloo 2009, 86-104.

Foucault, Michel 1972. "The Discourse on Language." In The Archaeology of Knowledge and the Discourse on Language, 215-37. New York: Pantheon.

Fraser, Nancy. 1990. "Gender, Citizenship, and the Public Sphere: Toward a Feminist Reconstruction of Habermas." Paper presented at Feminist Theory conference, Utrecht, May.

Goldberg, David Theo. 2006. "Racial Europeanization." Ethnic and Racial Studies 29(2):331-64.

Haavio-Mannila, Elina. 1993. "Women in the Workplace in Three Types of Societies." Report, Center for the Education of Women, University of Michigan, Ann Arbor. 
Hancock, Ange-Marie. 2007. "When Multiplication Doesn't Equal Quick Addition: Examining Intersectionality as a Research Paradigm." Perspectives on Politics 5(1):63-79.

2009. "An Untraditional Intersectional Analysis of the 2008 Election." Politics and Gender 5(1):96-105.

Hankivsky, Olena, and Renee Cormier. 2011. "Intersectionality and Public Policy: Some Lessons from Existing Models." Political Research Quarterly 64(1): 217-29.

Hannett, Sarah. 2003. "Equality at the Intersections: The Legislative and Judicial Failure to Tackle Multiple Discrimination." Oxford Journal of Legal Studies 23(1): 65-86.

Kantola, Johanna. 2010. Gender and the European Union. Basingstoke: Macmillan.

Katz, Michael B., Mark J. Stern, and Jamie J. Fader. 2005. "Women and the Paradox of Economic Inequality in the Twentieth Century." Journal of Social History 39(1):65-88.

Kenny, Meryl, and Fiona Mackay. 2009. “Already Doin' It for Ourselves? Skeptical Notes on Feminism and Institutionalism." Politics and Gender 5(2):271-80.

Krizsán, Andrea, Tamás Dombos, Erika Kispéter, Linda Szabó, Jasminka Dedić, Martin Jaigma, Roman Kuhar, Ana Frank, Birgit Sauer, and Mieke Verloo. 2009. "Framing Gender Equality in the European Union and Its Current and Future Member States." QUING report, Institut für die Wissenschaften vom Menschen, Vienna. http://www.quing.eu/files/results/final_larg_report.pdf.

Krizsán, Andrea, Hege Skjeie, and Judith Squires, eds. 2012. Institutionalizing Intersectionality: The Changing Nature of European Equality Regimes. Basingstoke: Macmillan.

Lombardo, Emanuela, Petra Meier, and Mieke Verloo, eds. 2009. The Discursive Politics of Gender Equality: Stretching, Bending and Policymaking. Abingdon: Routledge.

Lombardo, Emanuela, and Lise Rolandsen Agustín. 2012. "Framing Gender Intersections in the European Union: What Implications for the Quality of Intersectionality in Policies?" Social Politics 19(4):482-512. doi:10.1093/sp/jxr001.

Lombardo, Emanuela, and Mieke Verloo. 2009. "Institutionalizing Intersectionality in the European Union? Policy Developments and Contestations." International Feminist Journal of Politics 11(4):478-95.

Martinez, Elisabeth. 1993. "Beyond Black/White: The Racisms of Our Times." Social Justice 20(1-2):22-34.

McCall, Leslie. 2005. "The Complexity of Intersectionality." Signs: Journal of Women in Culture and Society 30(3):1771-1800.

Meier, Petra, and Karen Celis. 2011. "Sowing the Seeds of Its Own Failure: Implementing the Concept of Gender Mainstreaming." Social Politics 18(4):469-89.

NextGENDERation. 2004. "Niet in onze naam!" [Not in our name!]. De Standaard, March 8. http://www.nextgenderation.net/projects/notinournames /nederlands.html. 
O’Cinneide, Colm. 2002. "A Single Equality Body: Lessons from Abroad.” Equal Opportunities Commission's Research Discussion Series and Working Paper Series, Working Paper no. 4, Equal Opportunities Commission, Manchester. http://www.mfsd.org/crepub/A\%20Single\%20Equality\%20Body\%20Lessons \%20from\%20abroad.pdf.

Orloff, Ann Shola. 1996. "Gender and the Welfare State.” Working Paper 1996/ 79, Instituto Juan March de Estudios e Investigaciones, Madrid. http://www .march.es/ceacs/publicaciones/working/archivos/1996_79.pdf.

Parken, Alison. 2010. "A Multi-strand Approach to Promoting Equalities and $\mathrm{Hu}$ man Rights in Policy Making." Policy and Politics 38(1):79-99.

Risse, Thomas, and Stephen C. Ropp. 1999. "International Human Rights Norms and Domestic Change: Conclusions." In The Power of Human Rights: International Norms and Domestic Change, ed. Thomas Risse, Stephen C. Ropp, and Kathryn Sikkink, 234-78. Cambridge: Cambridge University Press.

Roggeband, Conny, and Mieke Verloo. 2007. "Dutch Women Are Liberated, Migrant Women Are a Problem: The Evolution of Policy Frames on Gender and Migration in the Netherlands." Social Policy and Administration 41(3): 271-88.

Rummens, Stefan. 2009. "Democracy as a Non-hegemonic Struggle? Disambiguating Chantal Mouffe's Agonistic Model of Politics." Constellations 16(3): 377-91.

Satterthwaite, Margaret L. 2005. "Crossing Borders, Claiming Rights: Using Human Rights Law to Empower Women Migrant Workers." Yale Human Rights and Development Law Journal 8:1-66.

Schmidt-Gleim, Meike, and Mieke Verloo. 2003. "One More Feminist Manifesto of the Political." IWM Working Paper no. 2/2003, Institut für die Wissenschaften vom Menschen, Vienna. http://iiav.nl/epublications/2003/One _more_feminist_manifesto.pdf.

Siim, Birte. 1994. "Engendering Democracy: Social Citizenship and Political Participation for Women in Scandinavia." Social Politics 1(3):286-305.

Siim, Birte, and Hege Skeje. 2008. "Tracks, Intersections and Dead Ends: Multicultural Challenges to State Feminism in Denmark and Norway." Ethnicities $8(3): 322-44$.

Squires, Judith. 2000. Gender in Political Theory. Cambridge: Polity.

Strolovitch, Dara Z. 2006. "Do Interest Groups Represent the Disadvantaged? Advocacy at the Intersections of Race, Class, and Gender." Journal of Politics 68(4):894-910.

- 2007. Affirmative Advocacy: Race, Class, and Gender in Interest Group Politics. Chicago: University of Chicago Press.

Stuve, Olaf, Elli Scambor, Marion Fischer, Majda Hrzenjak, Ziva Humer, Marie Wittamer, Sophie Künstler, et al. 2011. "Intersectional Peer Violence Prevention.” Handbook, Dissens e.V., Berlin. http://www.intersect-violence.eu/images /stories/handbook/intersect_violence_complete.pdf. 
Tilly, Charles. 1998. Durable Inequality. Berkeley: University of California Press. Van den Brink, Marieke, Yvonne Benschop, and Willy Jansen. 2010. "Transparency in Academic Recruitment: A Problematic Tool for Gender Equality?" Organization Studies 31(11):1459-83.

Verloo, Mieke. 2001. "Another Velvet Revolution? Gender Mainstreaming and the Politics of Implementation." IWM Working Paper no. 5/2001, Institut für die Wissenschaften vom Menschen, Vienna. http://www.aletta.nu/epublications /2001/anothervelvetrevolution.pdf.

_ 2005. "Displacement and Empowerment: Reflections on the Concept and Practice of the Council of Europe Approach to Gender Mainstreaming and Gender Equality." Social Politics 12(3):344-65.

_. 2006. "Multiple Inequalities, Intersectionality and the European Union." European Journal of Women's Studies 13(3):211-28.

, ed. 2007. Multiple Meanings of Gender Equality: A Critical Frame Analysis of Gender Policies in Europe. Budapest: Central European University Press.

2009. "Intersectionaliteit en interferentie: Hoe politiek en beleid ongelijkheid behouden, bestrijden en veranderen" [Intersectionality and interference: How politics and policy preserve, fight and change inequality]. Inaugural lecture, Radboud Universiteit Nijmegen, September 18, Nijmegen.

- 2011. "Gender Equality Policies as Interventions in a Changing World." Keynote address at the second European Conference on Politics and Gender, January, Budapest. http://www.ru.nl/politcologie/@678123/pagina/.

Verloo, Mieke, Petra Meier, Sophie Lauwers, and Saskia Martens. 2012. "Putting Intersectionality into Practice in Different Configurations of Equality Architecture: Belgium and the Netherlands." Social Politics 19(4):513-38. doi:10.1093 /sp/jxs021.

Verloo, Mieke, and QUING Consortium. 2012. "QUING Final Report.” Quality in Gender Equality Policies report, Institut für die Wissenschaften vom Menschen, Vienna. http://www.quing.eu/files/QUING_Final_Report_Jan 12 .pdf.

Walby, Sylvia. 2005. "Gender Mainstreaming: Productive Tensions in Theory and Practice." Social Politics 12(3):321-43.

- 2007. "Complexity Theory, Systems Theory, and Multiple Intersecting Social Inequalities." Philosophy of the Social Sciences 37(4):449-70.

. 2011. The Future of Feminism. Cambridge: Polity.

Walby, Sylvia, Jo Armstrong, and Sofia Strid. 2012. "Intersectionality and the Quality of Equality Architecture." Social Politics 19(4):446-81. doi:10.1093sp /jxs015.

Waylen, Georgina. 2009. "What Can Historical Institutionalism Offer Feminist Institutionalists?" Politics and Gender 5(2):245-53.

Weldon, S. Laurel. 2008. "Intersectionality." In Politics, Gender and Concepts: Theory and Methodology, ed. Gary Goetz and Amy G. Mazur, 193-218. Cambridge: Cambridge University Press. 
Woodward, Alison E. 2012. "From Equal Treatment to Gender Mainstreaming and Diversity Management." In Gendering the European Union: New Approaches to Old Democratic Deficits, ed. Gabriele Abels and Joyce Marie Mushaben, 85-103. Basingstoke: Macmillan.

Yanow, Dvora. 2003. Constructing "Race" and "Ethnicity" in America: CategoryMaking in Public Policy and Administration. Armonk, NY: Sharpe.

Yanow, Dvora, and Marleen van der Haar. 2012. "People Out of Place: Allochthony and Autochthony in the Netherlands' Identity Discourse-Metaphors and Categories in Action." Journal of International Relations and Development, electronically published June 29. doi:10.1057/jird.2012.13.

Young, Iris Marion. 1995. "Gender as Seriality: Thinking about Women as a Social Collective." In Rethinking the Political: Gender, Resistance, and the State, ed. Barbara Laslett, Johanna Brenner, and Yesim Arat, 99-124. Chicago: University of Chicago Press.

Yuval-Davis, Nira. 2006. "Intersectionality and Feminist Politics." European Journal of Women's Studies 13(3):193-209. 